\title{
1. The governance and politics of migration: a conceptual-analytical map
}

Emma Carmel, Katharina Lenner and Regine Paul

\section{INTRODUCTION}

The mobility of people is a commonplace of the contemporary world. Nor is this really a new or radically exceptional phenomenon. Migration for trade; for raids, conquest and settlement; for cultural exchange and learning; for enforced labour, and from conflict, have been integral to the development of human history. Nonetheless, the form, patterns, and experiences of such migrations - as well as conceptions and appreciations of them - have varied by time and place. And political and governmental action have always been central to this variation. At the time of writing, governments around the world have extended and intensified their strategies of mobility control in response to the global COVID-19 pandemic. Exclusion and expulsion are partnered with immobilisation in new ways, and gain new justifications, for the supposed protection of health and economic development. Long-settled policies for labour migrants have been overturned in weeks or even days. These measures, and their consequences, challenge the social and economic infrastructure across and between global North and South. They highlight the integral role played by migrant workers in health, care, food production, waste and transport systems, as well as the expendability of migrants in the face of other political priorities.

The possibility, practice and experience of migration is closely related to the efforts of public authorities to prevent, encourage or channel it. This includes attempts to 'import' or 'export' labour (e.g. Cohen 2006; Piore 1979); to use emigrants as resources in domestic economic and political projects (e.g. Boccagni et al. 2016; Weinar 2019); or to define who counts as unwanted and thus 'illegal' (e.g. Chavez 2007). In turn, the possibility, practice and experience of governance is closely related to how public authorities conceptualise and act on migration as part of population management within their territories (Bhambra 2017; Foucault, 2007). After all, governing (specifically defined) peoples in (specifically defined) places is integral to collective rule and ideas of modern statehood (Torpey 2000; more generally, see Jessop 2016). And the politics of collective rule is integral to determining which peoples are governed in which places, and in what ways.

This central duality of migration governance underpins this volume: that understanding governance sheds light on the specific forms and processes of migration, and that understanding migration sheds light on specific forms and processes of governance. This duality, however, is not a fixed relationship, but one that varies by time and place. It is also not confined to formal government action and institutions. Organising who moves when, where, how and why, are central preoccupations for local and transnational public authorities. But they are also affected by the actions of NGOs, trade unions, technology companies and banks, and every kind of employer from global South to global North. Policy, legal and institutional innovations often follow in the wake of migrations, whether they are to selectively mobilise and immobilise specific people; to induce development; and/or to enhance territorial claims 
(Raghuram 2009; Torpey 2000). As a result, both the institutions and purposes of governing are shaped by migrations. In turn, while migrations and migrants' experiences are not determined by their governance and politics - migration is 'autonomous' from its governance (Anderson 2017; Castles 2004) - nonetheless they are profoundly shaped by it. Studying the politics and governance of migration involves explanations of the mutual significance and implications of mobility and governance in different times and places.

As migration experiences, on the one hand, and the governance and politics of migration, on the other, are intrinsically and complexly interwoven, scholarly work must explain this duality and make it visible. Yet it must also attend to how governance and migration experiences are produced in practice, at multiple interconnected sites and across different scales. Rather than treating migration as an objectively observable - and governable - phenomenon, we explore how actors' specific perceptions of migration shape possibilities for political action and policymaking (see also Geddes and Scholten 2016: 3). We explain the micro-politics of migrant experiences and how these shape governance practices on the ground. Such micro-politics are always embedded in, and structured by, the wider power relations between places and social groups. To study the governance and politics of migration is to recurrently reflect back on how governance in one place affects mobility in another; to explain the interdependence of my migration with someone else's immobility. It is from this starting point that this Handbook addresses the governance and politics of migration: as dynamic, relational and still highly structured, with profoundly unequal and contested consequences across the world.

Migration governance is about more than policy or political problems and their solutions. Migrants are not just objects to be governed, and migration governance not only emerges from technical decisions on how to make migrants move, settle, move on, integrate and/or return. Migrants live, love, laugh, have ambitions, face setbacks, suffer and resist. The contingency and diversity of migration and migrants' lives exhibits multiplicitous, fractured, and largely ungovernable human complexity. Migration governance usually involves attempts to simplify, classify and regularise these, through general rules for action (Rose 1999; Scott 1998; Sharma 2015). These efforts are highly political in their origins and their effects, even when expressed in universal, or problem-solving terms. Like governance more generally, migration governance purposefully disguises its political origins and the unequal relations of power that sustain it (Bourdieu 1991; Fanon 2008 [1967]; Wynter 2003). Yet despite the ubiquity of migration, and of attempts to govern it, migration governance remains a site of struggle and contestation.

It is this foundational position that gives the Handbook its identity and coherence in defining the field of study. The Handbook sets out to define and extend the contours of contemporary research and theorising and situate them in a critically minded appraisal of the governance and politics of migration. We bring key perspectives from a range of disciplines into dialogue with one another, to examine crucial intellectual and research contributions to the field and its debates over the last 20 years. Our contributors offer significant critiques of myopic conceptualisations, limited scope of empirical research, dominant perspectives and narrowly defined objects of analysis. At the same time, they set out significant emerging theorisations and new research in the field.

In the next section of the introduction, we outline in more detail the conceptual approach and distinct epistemological position that underpins contributions to the Handbook. We discuss 'governance' and 'politics' each in turn, to explain how they are used in the remainder of the book. The section closes with a critical reflection on the politics of researching this field. In the subsequent section, we explore three 'constitutive contradictions' (Heinelt 1993) of 
migration governance and politics that emerge from discussions in this volume. Synthesising the findings in this book, we argue that the governance and politics of migration are constituted from the contradictions between their

- conceptual framing and material expression;

- global scope and relational practice;

- structured form and dynamic changeability.

The final section of this introduction explains the organising rationale for the book's structure and the role of each section for understanding the governance and politics of migration.

\section{THEORISING THE GOVERNANCE AND POLITICS OF MIGRATION}

In order to grasp the duality of migration and its governance and politics from a critical scholarly perspective, we conceptualise 'governance and politics' as concerned with (1) 'regimes of governing practices' (Carmel, 2019), and (2) political contestation. This approach enables our contributors across the whole Handbook to explore a range of practices as well as challenges to them, and to examine how they exert specific material effects on political, economic and social relations; including, and beyond, migration.

\section{Migration Governance as Regimes of Governing Practices}

In this Handbook and elsewhere, we treat governance as 'regimes of governing practices' (Carmel 2019: 24-46). In doing so, we take a multi-scalar perspective on the interaction of global structural conditions; specific policymaking processes; and the everyday decision-making of actors involved in migration governance (ibid.). Our starting point is that migration governance both resides in highly structured and unequal relationships of power and is also made and remade in everyday action (Carmel 2019; Lenner 2020; Però 2011; Pott et al. 2018; Shore et al. 2011). The iteration of governing practices over time produces and reproduces certain forms of rule and institutions that acquire a taken-for-granted character. Yet, governing practices are assembled from contingent and often contradictory actions of multiple actors and can have powerful effects without being coherent (Mosse 2004; Stone 2012; Wedel et al. 2005). Our approach therefore highlights the structural conditions, long-term forces and power relations that shape possibilities for political and policy action. But these conditions are never completely fixed; they are always subject to reconstruction and transformation by social actors, whether migrants, policymakers or others (cf. Jessop 2016). Micro-level interactions between migrants and different types of officials in these structured and unequal contexts are often as relevant for migrants' experiences and life trajectories, as are international or national regulations (Brachet 2016; Gaibazzi 2017; Hoag 2010): they unfold and are enacted together in a 'regime' of governing practices (Carmel 2019).

Our approach involves a close examination of the power dynamics that shape the governance of migration in different settings. This includes analysing how dominant social actors purposefully obscure the power relations inherent in this process. In this, mundane policy and administrative procedures really matter: consider the use of digital and biometric technologies for food payments in refugee camps; the creation of special categories of visa for 'entrepre- 
neurs' or the 'highly skilled'; the requirement for appeals against asylum decisions to be lodged in person, or at a particular time. These are all highly political measures, rationalised by policymakers and legislators as neutral, technical instruments of law and/or as 'common-sense'. They are enacted as practical measures for the orderly and utilitarian management of mobility. Yet other groups of actors, including migrants themselves, challenge, reify or subvert these 'common-sense' strategies, to create new possibilities for governance and political action.

Central to these power dynamics in particular settings are definitions of what migration is, and who counts as what kind of migrant. Our contributors critically examine concepts and categorisations of migration as both historically contingent and politically salient. The materialisation of these categorisations in specific governing practices expresses the self-image of dominant players in migration governance and their attempt to manage global migration flows (see e.g. Landau and Achiume 2017). In Part I, for example, our Handbook contributors review key concepts of migration governance, such as citizenship, national state or border, to highlight why, how and with what effects these have been normalised as foundations for usually exclusionary, sometimes deadly, governance practices. In Part II of the Handbook, we assess the emergence of distinctions between migrations and types of migrants. Contributors identify the conflicts they have obscured, and examine the shifting practices of governing through these categorisations in various historical and geographical contexts (see e.g. Bakewell 2008; Chimni 1998; Long 2013; Mayblin 2014; Paul 2015, 2016; Crawley and Skleparis 2017).

Our conceptual approach to governance is explicitly interdisciplinary. Political science and economics scholars - as well as policymakers - have commonly sought to explain why countries might favour particular immigration (and much more rarely, emigration) policies. In this, they have focused on sectoral interests and political representation (e.g. Cornelius et al. 2004; de Haas et al. 2018; Freemann 1995; Hollifield 1992; Joppke 1998; Menz 2009; Ruhs 2013). This important but conventional picture is enriched by understanding how international political economy, geo-politics and international relations shape who migrates, where and under what conditions (e.g. Berggren et al. 2007; Geiger and Pécoud 2010; Hansen and Jonsson 2014; Lee 2013). Contributions from sociology, anthropology and geography, but also constructivist political science, explore what it means to migrate, or to be a migrant (e.g. Amaya-Castro 2011; Andersson 2014; Baldaccini et al. 2007; De Genova 2013; Eule et al. 2018; Huysmans 2000; Schwenken and Ruß-Sattar 2014; Sigona 2014; Triandafyllidou 2019). They also speak to the wider relations of power, political authority and political economy in which migration and its governance are embedded (cf. Anderson 2019; Paul 2015; Pott et al. 2018; Rijken and de Lange 2018). Along with critical legal perspectives, they draw attention to the unequal implications of policies and politics (e.g. Anderson 2013; Carmel et al. 2019; Coddington, 2020; Tilly 2011). Thus, in Parts III and V of this volume, our contributors highlight the contingency and structural power of institutions at different scales. They identify the structured and structuring effects of migration governance hidden in technocratic tools and mundane governance processes. In doing so, these contributions also 'speak back' to a wider conceptualisation of politics.

\section{Migration Politics}

Mainstream studies of the 'politics' of migration have been traditionally conceptualised rather narrowly around the institutional politics of migration within nation states, and frequently just within destination states (see critiques in e.g. Amelina and Faist 2012; Meeus 2016). However, 
'politics' does not just reside in institutions. Institutions are not suitable proxies for analysing power and the dynamics of political interaction, particularly in the case of migration. The politics of migration, and of migration governance, are relational and multi-scalar. They are inextricably linked with wider relations of political economy; post- and neo-colonialism; and social inequalities, as well as the institutions and forces that shape them.

In this Handbook, we treat the study of politics as the study of power/authority, its contestation and their combined effects. Analytically, such political relations of power are revealed in resistance and contestation as well as in institutional authority, rule-making and brute force. As such, we are concerned with the ways in which politics plays out between formal institutions and informal exchanges among social actors. The politics of migration(s) are conditioned by structural factors, although these can be subject to rupture as well as gradual change. These include symbolic power and discursive resources; technologies of government; and conduits of money and violence, as well as intersectional inequalities, such as race, class, gender, age, sexuality and disability (Amelina and Lutz 2019; Crenshaw 1991).

Our contributors examine migration politics from this conceptual vantage point. They analyse actors' changing interpretations of the structural conditions they face, and how this affects their actions in particular settings. But they also examine how these interpretations and actions can affect the wider political economy, and power relations between particular places and institutions (often in unintended ways). Contributors show how wider social inequalities of gender, race, class, age or sexuality interact with specific legal statuses of migration. They explore the grey area between policies 'on paper' and practices on the ground to shed light on hidden social spaces where migrants' lived experience and biographies create new forms of social and political action, contradicting dominant narratives.

Treating politics as practices of power/authority enables us to explore how political actors seek to structure the social, economic, geographical and political spaces inhabited by 'others'. And how this governance is subverted or resisted, too. For example, the designation of 'legal' or 'illegal' entry and residence in national states is shaped by historically established inequalities including colonial encounters, as well as gendered and racialised forms of governing mobility (cf. Anderson 2013; Ellermann 2020; Hansen and Jonsson 2014; Kofman and Raghuram 2013; Mayblin and Turner 2020; Paul 2015). However, to understand the politics of this distinction and how it is governed, we need to attend to how it works 'on the ground'. As they move through their daily lives, migrants' experiences can be marked by liminality (e.g. Menjívar 2006) as their status is subject to diverse and incongruent regulatory conditions, both formal and informal. Migrants' rights as workers often stand in contrast to their rights of residence or their rights as family members (cf. Carmel and Paul 2013; Chauvin and Garcés-Mascareñas 2012; Lenner and Turner 2019; Ruhs 2013). And in turn, these intersect in complex ways with legal regulations and custom and practice, to shape migrants' gendered and racialised transnational access to social security (e.g. Amelina, Carmel et al 2019; Ataç and Roseberger, 2019; Vintila and Lafleur, 2020). It is in day-to-day practices that power inequalities come to matter, and the political contestedness of migration is expressed.

Each contribution of the Handbook engages in its subfield and theme to explore how migration politics and governance are contested and practised in different places through diverse categories, regimes, spatial relations and processes. Two specific sections do so in a more targeted manner: Part IV is dedicated to space-specific analysis of practices of migration governance. Contributions examine how particular spaces of destination, origin and transit are imagined, produced and experienced. In addition, Part VI discusses key arenas of contestation 
to dominant regimes of migration governance. Contributions assess how different forms of mobilisation around migration governance emerge, as well as their effects on power relations, and the allocation of entitlements and rights for migrants.

\section{Migration Governance Research as Both Governance and Politics}

Migration governance is intimately bound up with the politics of research and the political economy of knowledge production (Anderson 2019; Sukarieh and Tannock 2019). Academic research, and the ways in which scholars generate and contest knowledge, significantly shape how migrants are imagined and governed. This makes the politics of such knowledge generation integral to our study of the politics and governance of migration more generally.

In this Handbook, we show how particular ways of seeing migration and its governance are themselves political. When researchers seek research funding from the governments of receiving states or regional authorities; when we act as expert-advisors to governments or other public authorities; or when we work as expert-advocates to NGOs and legal campaigners, we invoke different ideas about what migration is and who migrants are. We claim authority from diverse forms of knowledge about migration in order to justify specific ideas about its governance.

In some cases, the politics of knowledge generation is also associated with different (sub-) disciplines: typically, orthodox economic analysis of migration 'stocks' and 'flows' constitutes palatable and digestible knowledge for the policymakers of destination countries. It is more easily reproducible as visuals for committee presentations and 'data-driven' reports, which fit the institutional grammar of governmental decision-making. Indeed, this applies even when the 'data' is unreliable, fungible and indeterminate, as long as definitions and labels fit policymaker expectations (Bigo 2014; Crisp 1999; Landau and Achiume 2017; Taylor and Meissner 2020). As in any ecology of knowledge production, particular disciplines, even individual authors from high status institutions, usually in the global North, are better placed to establish their approach, knowledge and recommendations as authoritative to high-level policy and political actors (Santos 2015: 188ff; in practice, see Lenner and Turner 2019). Most of the time, at least. But even more complex anthropological or sociological studies, say of the living conditions of refugees in large camps in the global South, may be susceptible to using melodramatic narratives that reproduce stereotypical ideas about vulnerability and victimhood. Such ideas continue to shape the limits of political and policy debate within donor countries and international organisations (e.g. Hyndman and Giles 2011; Johnson 2011; Turner 2019).

Conceptualisations of migration and its governance are also predicated on subdivisions within our field of study. The attempt to separate forced migration studies from migration studies overall and treat it as an independent subfield with its own journals, conferences and so on, for example, has not only contributed to reinforcing the erroneous assumption of clearly distinguishable ('forced' vs. 'voluntary') migration flows. It has also led to a tendency to decouple forced migration studies from broader conceptual discussions about the politics of migration and its governance, as well as the ethics of researching it. This has often resulted in a policy-oriented research focus on those political institutions concerned with refugees and forced migrants, adapted to the categories they operate with, rather than challenging them (cf. Bakewell 2008).

This politics of knowledge about migration and its governance is of fundamental importance. Dominant ways of seeing and knowing the world reproduce privileged positions of 
those who simultaneously present 'authoritative knowledge' and signal what kinds of knowledge (about migration and its governance) are actually authoritative (Santos 2015, esp. 157-8; Tuhiwai-Smith 1999). For students of migration, however, the politics of presenting 'alternative' forms and sources of authoritative knowledge, especially that of migrants, is also not straightforward. It is certainly not straightforwardly emancipatory (cf. Hill Collins 2002; Sharma 2015). Alternative knowledges and co-produced or migrant-centred biographical and ethnographic accounts are still brought to metropolitan centres of power, such as donor governments, international NGOs or humanitarian organisations, in a system of knowledge production that rewards researchers for 'impact' and 'engagement'. This process is entangled with wider political relations, of post-colonialism and profoundly unequal economic development. Researchers, especially from well-funded universities in the global North rehearse and reproduce dominant positions and narratives that continue to position migrants as racialised objects of analysis, and re-work existing conceptualisations of how migrations and their governance are debated and understood (cf. Fiddian-Qasmiyeh with Fiori 2020; Grieve and Mitchell 2020). The common focus on South-North migrations, for example, tends to neglect dynamics of migration and migration governance in most of the world, which could enrich our conceptual tools and understandings (cf. Comaroff and Comaroff 2011; Fiddian-Qasmiyeh et al. 2020; Stel forthcoming). Indeed, in-depth ethnographic, 'migrant-centred' accounts exploring their agency can also provide policymakers with opportunities to develop new mechanisms of control, deportation and incarceration (Haile 2020). As Tuhiwai-Smith (1999: 1-20) argues, the inquisition of research can also act as the acquisition of personhood, social practices and value of those being 'researched' (p. 6) and of the 'field' of research. The re-writing and re-presentation of migrants' concepts and knowledge, in order to conform to dominant forms and practices then re-works them in ways that permit the reproduction of iniquitous ways of knowing and governing (El Qadim et al. 2020; Mignolo 2012; Mignolo and Walsh 2018; Wynter 2003).

The politics and political economy of knowledge production thus generates ways of seeing and knowing about migration governance, but it is also integral to migration governance. In acknowledgement of this, and to counter it, contributors to this book examine and challenge theoretical framings of what migration governance is, how it is produced and takes effect. They also review and critique empirical research on how migration and migrants are governed in particular places, times and settings, and seek to explicitly include contexts of the global South.

\section{STUDYING THE POLITICS AND GOVERNANCE OF MIGRATION}

So how does the conceptual focus on 'regimes of governing practices' (governance) and contestations of power/authority (politics) matter for the contribution of this volume overall? Our authors show how the governance and politics of migration emerge from three constitutive contradictions.

First, the governance and politics of migration are conceptually framed and understood, but materially expressed in ground-level practices in specific settings for specific migrants. As such, it is important to attend to the ways that migration, migrants and their governance are conceptualised and also to how those constructions are enacted to have material effects. Second, the governance and politics of migration have global reach. They affect, connect and 
disconnect people and institutions across space, but they are also experienced, undertaken and contested in specific places. They have their own forms that can still produce unexpected commonalities of experience in very different settings. Even in the same place, they are marked by uneven and diverse outcomes. Third, the politics and governance of migration are inscribed in socio-economic power relations and structures, power-laden and often iniquitous. They are highly structured and condition political action, but, through the interpretations and actions of social and political agents, they are also dynamic and subject to transformation. This book, both in structure and in individual contributions, purposefully makes these contradictory characteristics of migration governance visible, systematically analysable, and subject to critique.

\section{Conceptual and Material}

One of the Handbook's chief analytical contributions is an explicit and critical focus on the contested character of migration governance. Indeed, following our framework outlined in the previous section, we contend that the conceptualisation of the issues at stake in migration governance is itself political. It requires close analytical scrutiny to identify the consequences of how migration and migrants are conceptualised, why dominant conceptualisations prevail and how they are contested and transform over time.

Longstanding lines of theoretical argument involve classic questions of citizenship and belonging. Debates about the 'liberal paradox' of migration governance have been concerned with conflicts between claims to state sovereignty, on the one hand, and democratic commitments to individuals' rights against arbitrary state interventions on the other (cf. Faist and Özveren 2004; Hollifield 2000; Joppke 1998, 2005). However, notions of post-colonial belonging, universal rights and transnational citizenship have rightly challenged such conventional framings of how migrants belong, and how they secure rights in different places, including those places that are outside or beyond the state. When those denied citizenship take political action to claim their 'right to have rights' they challenge us to rethink what it means to be a member of a society or political community (Isin 2002; Nyers 2018). Another defining line of theoretical debate concerns whether and how policies should respond to the socio-economic interdependencies and global inequalities - created by uneven capitalist development - which shape migration patterns (Cohen 2006; Sassen 1999). When migration governance is explicitly made part of global 'development' governance, then both become subject to critique on the misuse of political and economic power to serve the interests of globally powerful states (see Raghuram 2009). Similar contentious questions about global responsibilities concern who can and should be subject to humanitarian protection (Chimni 1998; Crawley and Skleparis 2017; Saunders 2014). The climate emergency is used to expand definitions of refugee status, while threats of migration are used xenophobically to bolster campaigns for climate policies. Such pertinent debates are discussed in Part I of the volume.

Conceptualisations of migration, of migrants, and their governance have emerged in processes that are deeply political; and their effects are profound. We expose the politics of these conceptualisations and question the conventional presentation of particular categories of migrant as defined by international organisations or states. In this, we support Bakewell's (2008) call for 'policy-irrelevant' research: we set aside the ways in which policies conceptualise migration and migrants to be able to see them beyond state and policy-imposed categories.

Yet these categories and conceptualisations remain important because they are not abstract legal or political constructs without further implications. These conceptualisations and the 
theoretical narratives that underpin them, have direct effects when expressed in laws and regulations, in institutions and processes, and when materialised in physical objects of governance: from digital online forms to ID cards; in floating barrages used to exclude dinghies from coastal borderlands; and branded backpacks for children whose status as forced migrants warrants their receipt of international aid. ${ }^{1}$ Our intention is to make visible, and to explain, the power relationships between theoretical scholarly conceptualisations; dominant conceptualisations in governance; and migration governance practices.

A first analytical step is to identify the myopias of conceptual debates that define the study of migration governance and politics. All our contributors take this as a central task, acknowledging the situatedness of their critique, in, mostly, the 'global North', and in particular social science disciplines. Our contributors trace the history of such conceptualisations and their concrete effects in specific experiences of migration, family life and working conditions. They explore categorisations as political and legal artefacts that disguise the commonalities of migrants' experiences, both in relation to other migrants and non-migrants (Part II). They also show how bureaucratic rules facilitate the violence and control experienced by migrants, and how political forces are brought to bear to manage, or contest, the status quo (Parts III, V and VI). Overall, our contributors show that governance conceptualisations render some migrants highly visible, and targets of governance, while abandoning and invisibilising others. Just as importantly, they insist that it is the relationship between the dominant governance conceptualisations and strategies, and the marginalisation of other aspects of migration, that shapes migrants' lives and rights.

\section{Global and Relational}

Governing is a process which institutes relationships of power and possibilities of governing in highly contextualised ways. It is emplaced - politically, socially and economically - and articulated with wider conditions that mark the particularity of places and settings. And yet, such contextualisation ought not make researchers blind to the wider trends in migration governance, related knowledge biases, global power asymmetries and inequalities that underpin migration overall. It is therefore necessary to study the governance and politics of migration with a perspective on the global and relational character of distinct and yet connected governing practices and their contestation. At the same time, to acknowledge such connectedness also offers an opportunity to decolonise research - often dominated by conceptualisations stemming from the 'global North' (Mayblin and Turner 2020). To reconceptualise beyond normalised knowledge what migration is, and how it is experienced, our next analytical step is to fully acknowledge, and learn from, the 'pluriverse' (Mignolo and Walsh 2018) of knowledges about migration and its governance. Our contributors do so by exposing hegemonic discourses on migration governance and their implications as well as seeking to diversify research perspectives and empirical applications beyond 'Northern' academia, as well as research settings.

Methodological nationalism is a well-acknowledged, but persistent, obstacle to a full understanding of globally connected practices of migration governance. Conceptual framings of the state as the sole (sometimes monolithic) actor in migration governance have met with increasing criticism (cf. Wimmer and Glick Schiller 2002). Yet treating countries as "natural units for comparative analysis" (Garcés-Mascareñas 2019: 51) often continues for the sake of methodological ease. It may also be the product of a politics of research funding which often 
privileges large-n comparative studies and quantification that promise strict hypothesis-testing and index-building.

State-centred geographical markers of difference remain important, of course, as does large-n comparative work. Yet they are not the only spaces in which migration governance takes place and is experienced. The daily lives of migrants are regulated and contested in and across diverse spaces, which often transcend nation state borders. Such spaces include land or sea routes, which are reconstituted with changing international regulations (Walters 2015, 2017). They also comprise zones of transit and border processing (De Genova 2013). Yet even spaces of migration governance clearly located within nation state boundaries - e.g. refugee camps, cities, or rural areas - are not only determined by national governments, but equally shaped by international organisations, globalised technologies, donor politics and other states (cf. Amelina et al. 2019; Feldman 2011; Lenner 2020). Practices of migration governance can differ substantially depending on where migrants live, where they work, and under which conditions (Crowley 2001; Jaji 2011; Kofman 2013; Sigona 2014). These spatialised practices seek to manage migrants' relationships with each other, public authorities and their living spaces. They emerge from global inequalities, and frequently reproduce them. Yet they can also produce individual, everyday contestations, and even significant mobilisations through unionisation, legal action and political campaigning. These mobilisations are then sometimes able to re-connect sites of bordering, migration, exploitation and precariousness to challenge the life and work conditions in otherwise distant places (e.g. de Vries and Guild 2019; Rygiel and Nyers 2012; Schwenken and Ruß-Sattar 2014; Stierl 2015).

Flowing from methodological nationalism is also a methodological North-centrism (often also labelled 'Euro-centrism' or 'Western-centrism'), which assumes migration from the global South to the global North and political responses there to constitute the norm of current migration governance. Focusing on migration governance in 'Northern' settings, even if from a critical perspective, can easily end up disavowing ongoing relations between migration processes and wider governance practices (e.g. uneven economic developments connecting consumers with migrant agricultural labour, climate change effects or conflict and arms trade/ security involvement as shown in Feldman 2011; Medland 2017).

There is also much highly critical scholarship which, by drawing sharp distinctions between migration governance in global North and South, or by simply focusing on Northern contexts only, overlooks dynamics of governance that are, in fact, global (cf. e.g. Garcés-Mascareñas 2019; Jaji 2013; Natter 2018). There is need, for example, to understand the central role of ambiguity and informality of regulations and processes in reinforcing migrants' precarity in work, welfare, housing and family life (see e.g. Carmel et al. 2019; Nassar and Stel 2019; Oesch 2017). The same goes for the significance of social institutions and networks in shaping migrants' lives, complicating and/or opening up ways to cope with, circumvent, or challenge formal authorities (e.g. Scheibelhofer et al. 2019; Jacobsen 2006). There is much to learn from scholarship on migration governance in the global South, which can help transcend a bias towards formal institutions and get away from assuming fundamental differences in and of migration policy, for example between supposedly democratic vs. undemocratic regimes. This includes appreciating how Southern settings have served as laboratories for developing technologies of (migrant) population control, which are subsequently rolled out across the globe - the iris scan technology for refugees being only one of the latest in a long line of examples (cf. Jacobsen 2017; Sharma 2015). Scholarship that highlights similarities in processes and practices of migration governance across the globe, and/or the South to North routes of tech- 
nologies of control, productively contributes to provincialising some founding assumptions of Northern-centred scholarship, and helps in decolonising established frameworks of analysis, particularly in political science and political sociology (Comaroff and Comaroff 2011). Such decolonisation does not imply a hyper-contextualisation, which treats every experience of migration governance as specific and incomparable though. It rather highlights the relatedness of distinct phenomena and events across different sectors of governance, space and time.

Finally, an explicitly spatialised perspective not only acknowledges the simultaneous specificity and connectedness of migration governance and politics. It also helps to shed light on how spaces not usually seen as 'migration governance and politics' can play a strong role in regulating and shaping migrants' everyday lives, such as homes or workplaces. In sum, adopting a spatialised perspective on migration governance and politics enables us to see more clearly the multiple dimensions of the political.

\section{Structured and Dynamic}

Migration governance is characterised by relatively stable arrangements that structure and constrain how governing is done, and how governing practices are made sense of and acted upon by political actors (more generally, see Jessop 2016; Sum and Jessop 2013). As they become taken for granted, the inequalities that governance arrangements embody become more difficult to see, challenge and change. In particular, they are often occluded by the common-sense conceptualisations, and apparently technocratic ways of governing migration and migrants we discussed above. Over the longer term, such power and resource inequalities also become institutionalised as structural conditions that migrants, decision-makers and political stakeholders reproduce or simply work within.

As such arrangements are not politically neutral, scholars need to challenge their 'taken for granted' character. In this Handbook, authors explain how dominant structures in migration governance can come to be seen as such. They historicise their origins, and problematise contemporary practices. Governing regimes can be assembled in formal institutional arrangements such as the UN refugee agency, but also through informal and often hidden processes generated by political actors, whether in everyday decision-making or grand re-definitions of policy problems. Institutions and regimes may act in ways that change how migration is seen and acted on, even if they more usually reify existing relationships of power. While Part III is specifically dedicated to analysing such formal and informal governance regimes, all contributions address the question of structures and their effects from diverse conceptual vantage points and empirical angles.

Importantly, from our critical lens, we can see that the highly structured practices of migration governance are also deeply but often invisibly interwoven with (equally structured) processes of knowledge generation. These include, but are not confined to, risk-based technologies, 'real-time' maritime mapping, heat-detection and bio-technology regulated food assistance (Amoore and Hall 2009; Broeders and Hampshire 2013; Dijstelbloem and Meijer 2011; Duez and Bellanova 2012; Tazzioli 2019; Walters 2008). The use of these technologies makes a number of normative assumptions about the costs and benefits of migration which policymakers - and sometimes also researchers - take for granted or obscure despite their highly political implications (Paul 2019). As normative judgements about migration become inscribed into the complex technical and often covert models of risk analysis, their legitimacy 
and practical workings are even further removed from democratic scrutiny (Amoore 2020; Leese 2014, 2016; Tazzioli 2018).

However, exploring the structured and structuring purposes and effects of migration governance ought not to obscure simultaneous instances of transformation. While knowledge generation and its political uses often proceed quietly, they can also be undermined or become re-politicised, through individual acts of resistance or more sustained forms of mobilisation (Andersson 2014; Collyer 2012). Migrants may choose to defy categories they are placed in or to make strategic use of them. They may claim their vulnerability and victimhood in order to fit with categories such as 'victim of trafficking' or 'forced migrant' (e.g. O'Higgins 2012; Plambech 2014). Alternatively, they may challenge these definitions through practical action (Nyers 2018); not least through their migratory movements (e.g. Perkowski and Squire 2019). The politics of migration governance, however, is also transformed through anti-immigrant forms of mobilisation (Neocosmos 2008; Sassen 2014). In Parts V and VI, our contributors analyse different processes through which migration governance can be politicised, depoliticised, and re-politicised: demonstrating both the normalisation of migration governance and challenges to it.

\section{OUTLINE OF THE BOOK}

The conceptual and analytical approach outlined in the previous sections shapes how we examine the governance and politics of migration in the Handbook, including the book's overall organisation and presentation. As we have shown, politics inheres in governing practices, but these are not confined to government institutions, public authorities or laws. The governance of migration and migrants is dispersed across different sites: not just at borders, but in workplaces, homes and routes. It also varies by place and context, whether in grand global programmes or in the practices of police on the street.

This empirical diversity cannot be easily contained in the confines of a formal book structure. Indeed, we do not claim to do so. To systematise and then re-present the full range of institutions, rules, places, practices and experiences of migration governance and politics in a linear organisational format, would itself be a political act. As we contend that it is not possible to understand migration governance by looking at formal characterisations of 'types' of migration, or 'levels of governance', or regions of the world, so we do not use these to organise this Handbook. Such an approach would imply that migration governance is knowable through these characterisations, and as such can be acted on straightforwardly with regular effects. As we argued earlier in this introduction, and as our contributors show, such an approach would blind us to some of the most significant aspects of how migration and migrants are governed and how this governance is contested.

However, we still need an organising framework, to present the wide-ranging and in-depth contributions of this volume, and their intersection. Our choice for the structure of the volume follows from our emphasis on a conceptual-analytical, rather than an empirical-descriptive frame for the study of migration governance and politics. We have therefore organised this Handbook to address what we view as the six key dimensions of governance and politics of migration: (1) conceptualisations of migration governance and politics and how they have been understood and debated; (2) categorisations of migration and migrants that underpin key ways in which migration has been governed and contested; (3) regimes of migration 
governance that express the contingent but institutionalised forms through which migration is structured; (4) the spaces in and through which migrants' lives are shaped, mediated and experienced; (5) the processes through which governing is enacted and materialised on the ground; and (6) key forms and processes of contestation and mobilisation for other ways of governing migration, and sometimes, other ways of doing politics. The remainder of this introductory chapter explains the rationale, focus and contributions in each of these sections, before concluding with some reflections on our scholarly and political position as editors.

\section{Part I: Conceptualising the Politics and Governance of Migration}

Part I deals with key debates through which scholars understand the governance and politics of migration, and the insights to be gained from their empirical application. As such, chapters in this section also forge a conceptual compass to navigate through the more empirically oriented sections of the Handbook. The book opens with three chapters on key theoretical framings of migration governance. Lucy Mayblin shows the potentially transformative effects of reading migration and its governance through de-colonial perspectives. Flávia Rodrigues de Castro and Carolina Moulin examine changes in theorisations of nationhood and citizenship, highlighting how they inform our understanding of migration governance, and how recent "critical mobility' approaches open new ways of viewing political action and citizenship. Carolin Fischer reflexively explores insights from revitalised scholarship on diaspora and transnationalism, to animate a rethinking of how key areas of migration governance and politics are strategically shaped by transnational action, and to move beyond methodological nationalism in such discussions. The following chapters in this opening section explain key lines of argument in how we theorise specific forms and conditions of migration governance and their politics. Karolina Follis explores how the border/security nexus in migration governance is shaped by contestation, and its limits, around three key concepts: sovereignty, security and risk. Lama Kabbanji uses a Gramscian perspective to identify and critique the current hegemonic model of the migration/development nexus, and the political relationships that this model disguises and reproduces. Ingrid Boas and Hanne Wiegel identify three waves of changes in the governance of the climate change/migration nexus, none of which accommodate the experiences and practices on the ground, and propose adopting a mobilities approach as an alternative. Jason Hart historicises the place of humanitarianism in migration governance and shows the tensions and compromises faced by humanitarian organisations as political and organisational dependence challenge principles of 'modern' humanitarianism. Katharina Natter closes the section by unravelling dominant dichotomies in political science theories on immigration in different political regimes to make a case for new frameworks that facilitate research and theorising beyond the global North/global South divide. Across all these contributions, the emphasis is on teasing out the historical, social and political contexts within which theorisations of migration governance have developed. All the authors identify the need for further critical reflexivity and closer theoretical engagement with the politics of migration governance in practice.

\section{Part II: The Politics of Categorising Migration}

The premises on which the current governance and politics of migration are built can only be understood through an examination of specific socially constructed categories of migrant (among numerous others, e.g. Bakewell 2008; Carmel and Paul 2013; Crisp 1999; Paul 2015). 
Part II therefore covers key issues and debates on how different 'types' of migration are governed through categorisations, how these categorisations have emerged as distinct, and how the politics of migration is shaped through them. Chapters also consider how resulting categories of migrants are being contested and how they shape migrants' experiences of inclusion and exclusion. It is in these chapters that we see the close examination of how wider forces and conditions, in the politics of class, gender, ethnicity and colonialism, intersect with the development and enactment of these categories. Oliver Bakewell dissects how the distinction between forced and voluntary migration powerfully shapes the lives and opportunities of migrants, whose journeys more often than not involve elements of force as well as choice. Vicki Squire examines how illegality is systematically produced as a condition that reinforces the precarity of those migrating to search for a better, safer life. Cameron Thibos and Neil Howard look at the discourse and politics of human trafficking, and question the distinction between victims, non-victims and facilitators that it has engendered. Saskia Bonjour and Laura Cleton analyse the politics of constructing family as a legal ground for the admission of foreigners, and the inclusions and exclusions produced by this category. Finally, Huw Vasey outlines how skill has become a powerful social construct that classifies and stratifies migrants into distinct groups. Across contributions, authors question those powerful categories of contemporary migration governance not only by historicising them, but also by outlining how migrants strategically employ, undermine as well as openly contest them, and outline alternative conceptualisations that make visible the politics of producing those categories in the first place.

\section{Part III: Institutions and Regimes of Migration Governance}

Part III is concerned with how the iteration of governance practices over time produces relatively stable institutional arrangements for migration governance. Contributions interrogate how such regimes are assembled, how they come to be taken for granted, and how they - often rather invisibly and informally - shape migration governance beyond simplistic notions of origin, destination and transit. They examine the key components that mark out each governance regime, and how its development over time has been shaped by contestations among different actors, including migrants. They explore how governing strategies and mechanisms are articulated with underlying normative positions to generate a particular regime, and how and to what effect regimes accentuate, amplify but also silence specific issues in the governance of migration. Prem Kumar Rajaram starts with a discussion of border regimes as relational accounts of space and invites us to critically study their particular regime function: to reproduce dominant social relations. Heaven Crawley and Mary Setrana outline the evolution of the global refugee regime and highlight that without reclaiming a meaningful universal concept of protection, governance efforts such as the Global Refugee Compact are bound to reproduce global inequalities and risk of death. Antoine Pécoud deconstructs the global discourse on migration management as a deliberately depoliticising and seemingly consensual approach which glosses over deep disagreements over how to actually govern migration as well as the inequalities such governance (re-)produces. Shamel Azmeh explores how the mutual constitution of global value chains and the governance of migrant workers deepen global social and economic inequalities. Nora El Qadim discusses national state regimes as the prevailing stronghold of dominant interpretations of legitimate exclusion, while exposing them as complex arrangements riddled with contradictions and constantly in flux. 


\section{Part IV: Spaces of Migration Governance}

Chapters in Part IV interrogate how the daily lives of migrants are regulated and contested in and across diverse spaces. Beyond nation states, this section examines how the governance and politics of migration are spatialised in de-centred, complex and deeply contingent ways, and how these affect the practices and experiences of migrants. Contributors explore how the governance of migration expresses the characteristics of each such space, its social relations internally and with other spaces, and how these spaces are connected to broader regimes and dynamics of migration governance. William Walters argues that the idea of migration routes in policy and expert discourses needs to be denaturalised, and promotes the notion of migrant journeys as an alternative concept that allows more space for a diversity of migrant experiences. An van Raemdonck and Fran Meissner review scholarship on urban migration governance which, they argue, needs to extend beyond analysing levels of regulation, and explore migrants' roles as city makers, as migrant and non-migrant city dwellers interact. Lydia Medland investigates the significance of rural areas as sites of migration governance, and problematises the metropolitan focus, as well as the urban-rural dichotomy permeating much of the scholarship on migration governance. Lewis Turner's analysis of camps demonstrates that for inhabitants, the meanings of encampment are much more diverse than indicated in current scholarship based on Agamben's notion of the camp. Tesseltje de Lange, Lisa Berntsen and Pedro de Sena explore the entanglement of political economy, migration governance and (the lack of) labour mobility rights in workplaces, focusing on three workplaces typically associated with migrant labour. Finally, Sabrina Marchetti and Anna di Bartolomeo analyse homes as sites of migration governance, focusing on the experiences and struggles of domestic workers, and the multiple regimes of governance they are subjected to.

The list of spaces covered in this section is not exhaustive. They obviously also include the border as a space of governance that is simultaneously violent but also diverse in its workings and effects. Other important spaces that could and have been analysed with similar questions in mind include detention facilities (e.g. Bayles and Mayblin 2018; Moran et al. 2013), courts (see e.g. Gill et al. 2015) or religious spaces. Focusing on specific spaces in a handbook on migration governance overall, however, directs attention to the fact that concepts such as 'country of destination' or 'international regimes of migration governance' do not do justice to the variety of spatialised experiences of governance that shape migrants' lives and struggles at different points of their journeys or lives.

\section{Part V: Processes and Practices of Migration Governance}

An important analytical gateway into the conceptual underpinnings and material effects, but also the structured and dynamic character of migration governance, is to ask how and to what effect migration is governed through different processes. In what ways do the processes under scrutiny - such as the technologisation of migration control, the criminalisation of migration or outright deportation - make the politics of migration governance visible or invisible? Why and how do these processes become dominant in governing migration, and which type of actors and knowledge do they privilege and exclude? Contributions in Part V render visible the seemingly technical procedures for processing migrants and migration-related knowledge and the ways in which such procedures obscure political choices and implications. The section starts with Melanie Griffiths' overview of the temporal dimension of migration governance 
processes. She renders visible the powerful - but often implicit and analytically neglected - selectivity and control functions of time horizons, delays and accelerations, and temporal continuity and disjuncture in migration policies and governance. Julien Jeandesboz discusses how technological innovation and knowledge production affect the intensity, direction and effects of migration control endeavours. David Moffette addresses the widespread intermeshing of criminal law and migration law sanctions in legal practice ('crimmigration') from a legal pluralist perspective, exploring how multifaceted political games of 'cherry-picking' in and across legal subsystems work to control and punish migrants. Annika Lindberg and Shahram Khosravi take a procedural and temporal analytical perspective on how deportation and detention practices intermingle, in complex and staggered ways, with other processes to produce and sustain global inequalities. Overall, contributions in this section explore both how governance processes inform marginalisation as well as the ways in which they are being - and ought to be - contested.

\section{Part VI: Contesting Migration Governance}

Part VI is specifically dedicated to processes in which the politics of migration governance are being contested and re-politicised. Contributors assess how political mobilisations by, for and against migrants shape the politics of migration. They explore how both migrants and migrations are 'politicised' and 're-politicised' in these mobilisations. They examine the resources, strategies and tools that actors have at their disposal to contest migration governance practices, and their relative success and failure in different contexts. The section starts with a contribution on migrant political activism by Ilker Ataç and Helen Schwenken. They shed light on how our idea of 'the political' in migrant activism must include the formation of political subjectivities and everyday acts of empowerment vis-à-vis racialised, gendered and social discrimination. Leila Kawar's discussion of legal mobilisations examines judicially supervised contestations of immigration law, and their often unexpected 'radiating effects' on legislative and administrative policymaking. Nicola Piper's contribution on economic mobilisations highlights how a new conception of migrant rights is being forged around the notion of decent work, embedded in global social justice concerns and an emerging multi-actor governance architecture. The final chapter by Aitana Guia considers how anti-immigrant discourses and mobilisation actively transmit 'political-religious master frames' into the general public discourse about migration, usually with the effect of discrediting norms of 'liberal' governance.

\section{CONCLUDING REFLECTIONS}

As explained in the earlier sections of this introduction, our aim in this Handbook is threefold. First, we seek to provide readers with a clear conceptual frame for navigating this field of research. Second, we offer a guide to the governance and politics of migration as a field of study. Finally, we propose a reflexive, critical engagement with the state-of-the-art, in order to address, rethink and redefine the governance and politics of migration in the future. For the first, we conceive of migration and governance as mutually and fundamentally related, but not fixed. We draw from this starting assumption our conceptualisation of (1) governance as 'regimes of governing practices' (cf. Carmel 2019), and (2) politics as power/authority and its contestation. Taken together, and synthesising the findings from this Handbook, we propose 
that the governance and politics of migration inhere in three constitutive contradictions: conceptual/material; global/relational; and structural/dynamic. These contradictions can be observed and explored across six dimensions of migration governance and politics that define it as a field of study, as reflected in the structure of the Handbook.

Contributions to this volume more than met our desire to gather scholarly accounts which would portray the state-of-the-art on migration governance in an accessible manner and critically engage with it. While we outlined our conceptual and analytical approach before approaching our contributors, this is not the same handbook we originally imagined. In the long and rewarding process of developing this volume, our engagement and discussion with authors and their work has enabled us to develop, refine and clarify our own thinking. We encouraged contributors to closely examine the state-of-the-art, to historicise our understanding of the ways in which migration and migrants are governed in the contemporary world, and to critically review this governance, and research on it, with a strong sense of their own scholarly voice. We asked them to do all this while also closely attending to the emerging work and ideas that will come to shape the governance and politics of migration in the future. In response, contributors have indeed identified many challenges in our field of research that signal the need to transform how we think about migration governance and politics, and how we study them.

We need to continue deepening and extending the 'pluriverse' of knowledges (cf. Mignolo and Walsh 2018) on which migration governance and politics currently rest. The contributions in this Handbook point to a number of avenues that should be pursued in much greater depth when seeking to grasp the governance and politics of migration. We need to interrogate state and formal definitions of migration that disavow human relationships and connections across borders, both spatial and temporal. In doing so, we must reassess the relationships of state and political economy that are produced in migration governance. These include both the changing structural conditions of 'global' capitalism in general, as well as the concrete role played by individual corporate actors in diverse governance spaces and processes. Above all, we must re-centre the role of 'race' in how migration governance and politics produce intersectional inequalities around ethnicity, gender, sexuality, class and (dis)ability. This must include more nuanced attention to the politics of everyday migrant life through exploring the practices entangled between North and South, as well as shared possibilities for transnational political action. We hope that our readers will find the Handbook an enriching and rewarding experience to enter into, refresh or deepen, their own understanding of our field and, by taking up such challenges, contribute to its further development.

\section{NOTE}

1. An ongoing critical record of this institutional branding has been collated by Jeff Crisp, on Twitter, @.JFCrisp.

\section{REFERENCES}

Amaya-Castro, J. M. (2011), 'Illegality Regimes and the Ongoing Transformation of Contemporary Citizenship', European Journal of Legal Studies, 4 (2), 137-61. 
Amelina, A., E. Carmel, A. Runfors and E. Scheibelhofer (eds) (2019), Boundaries of European Social Citizenship, London: Routledge.

Amelina, A. and T. Faist (2012), 'De-Naturalizing the National in Research Methodologies: Key Concepts of Transnational Studies in Migration', Ethnic and Racial Studies, 35 (10), 1707-24.

Amelina, A. and Lutz, H. (2019), Gender and Migration: Transnational and Intersectional Prospects, London: Routledge.

Amoore, L. (2020), Cloud Ethics: Algorithms and the Attributes of Ourselves and Others, Durham, NC, Duke University Press.

Amoore, L. and A. Hall (2009), 'Taking People Apart: Digitised Dissection and the Body at the Border', Environment and Planning D, 27 (3), 444-64.

Anderson, B. (2013), Us and Them? The Dangerous Politics of Immigration Control, Oxford: Oxford University Press.

Anderson, B. (2017), 'Towards a New Politics of Migration?' Ethnic and Racial Studies, 40, 1527-37.

Anderson, B. (2019), 'New Directions in Migration Studies: Towards Methodological De-nationalism', Comparative Migration Studies, 7 (1), 1-13.

Andersson, R. (2014), Illegality, Inc. Clandestine Migration and the Business of Bordering Europe, Oakland: University of California Press.

Ataç, I. and Rosenberger, S. (2019), 'Social policies as a tool of immigration control', Journal of Immigrant and Refugee Studies, 17 (1), 1-10.

Bakewell, O. (2008), 'Research Beyond the Categories: The Importance of Policy Irrelevant Research into Forced Migration', Journal of Refugee Studies, 21 (4), 432-53.

Baldaccini, A., E. Guild and H. Toner (2007), Whose Freedom, Security and Justice?: EU Immigration and Asylum Law and Policy, Oxford and Portland, OR: Hart Publishing.

Bales, K. and L. Mayblin (2018), 'Unfree Labour in Immigration Detention: Exploitation and Coercion of a Captive Immigrant Workforce', Economy and Society, 47 (2), 191-213. DOI: 10.1080/03085147.2018.1484051.

Berggren, E., B. Likic-Brboric, G. Toksoz and N. Trimikliniotis (2007), Irregular Migration, Informal Labour and Community: A Challenge for Europe, Maastricht: Shaker Publishing.

Bhambra, G. K. (2017), 'The Current Crisis of Europe: Refugees, Colonialism, and the Limits of Cosmopolitanism', European Law Journal, 23 (5), 395-405.

Bigo, D. (2014), 'The (in)securitization Practices of the Three Universes of EU Border Control', Security Dialogue, 45 (3), 209-25.

Boccagni, P., J. M. Lafleur and P. Levitt (2016), 'Transnational Politics as Cultural Circulation: Toward a Conceptual Understanding of Migrant Political Participation on the Move', Mobilities, 11 (3), 444-63.

Bourdieu, P. (1991), Language and Symbolic Power, Cambridge, MA: Harvard University Press.

Brachet, J. (2016), 'Policing the Desert: The IOM in Libya Beyond War and Peace', Antipode, 48 (2), 272-92.

Broeders, D. and J. Hampshire (2013), 'Dreaming of Seamless Borders: ICTs and the Pre-Emptive Governance of Mobility in Europe', Journal of Ethnic \& Migration Studies, 39 (8), 1201-18.

Carmel, E. (ed.) (2019), Governance Analysis: Critical Enquiry at the Intersection of Politics, Policy and Society. Cheltenham: Edward Elgar Publishing.

Carmel, E. and R. Paul (2013), 'Complex Stratification: Understanding European Union Governance of Migrant Rights', Regions and Cohesion, 3 (3), 56-85.

Carmel, E., B. Sojka and K. Papiež, (2019), 'Beyond the Rights-Bearing Mobile EU Citizen: Governing Inequality and Privilege in European Union Social Security', in A. Amelina, E. Carmel, A. Runfors and E. Scheibelhofer (eds), Boundaries of European Social Citizenship, London: Routledge, pp. 46-72.

Castles, S. (2004), 'Why Migration Policies Fail', Ethnic and Racial Studies, 27, 205-27.

Chauvin, S. and B. Garcés-Mascareñas (2012), 'Beyond Informal Citizenship: Exploring the New Moral Economy of Migrant Illegality', International Political Sociology, 6 (3), 241-59.

Chavez, L. R. (2007), 'The Condition of Illegality', International Migration, 45 (3), 192-6.

Chimni, B. S. (1998), 'The Geopolitics of Refugee Studies: A View from the South', Journal of Refugee Studies, 11 (4), 350-74. 
Coddington, K. (2020), 'Producing Thailand as a Transit Country: Borders, Advocacy, and Destitution', Mobilities, 15 (4), 588-603.

Cohen, R. (2006), Migration and its Enemies: Global Capital, Migrant Labour and the Nation-state, Aldershot: Ashgate.

Collyer, M. (2012), 'Migrants as Strategic Actors in the European Union's Global Approach to Migration and Mobility', Global Networks, 12 (4), 505-24.

Comaroff, J. and J. L. Comaroff (2011), Theory from the South: Or, How Euro-America is Evolving Toward Africa, London: Paradigm.

Cornelius, W. A., Martin, P. L. and Hollifield, J. F. (eds) (2004), Controlling Immigration: A Global Perspective, 2nd edn, Stanford, CA: Stanford University Press.

Crawley, H. and D. Skleparis (2017), 'Refugee, Migrant, Neither, Both: Categorical Fetishism and the Politics of Bounding in Europe's "Migration Crisis"', Journal of Ethnic and Migration Studies, 44 (1), 48-64.

Crenshaw, K. (1991), 'Mapping the Margins: Intersectionality, Identity Politics, and Violence against Women of Color', Stanford Law Review, 43 (6), 1241-99.

Crisp, J. (1999), “"Who has Counted the Refugees?" UNHCR and the Politics of Numbers', New Issues in Refugee Research, Working Paper No. 12.

Crowley, J. (2001), 'Differential Free Movement and the Sociology of the "Internal Border"', in E. Guild and C. Harlow (eds), Implementing Amsterdam, Portland, OR: Hart Publishing, pp. 13-33.

de Haas, H., K. Natter and S. Vezzoli (2018), 'Growing Restrictiveness or Changing Selection? The Nature and Evolution of Migration Policies', International Migration Review, 52 (2), 324-67. doi: 10.1111/imre.12288.

De Genova, N. (2013), 'Spectacles of Migrant "Illegality": The Scene of Exclusion, the Obscene of Inclusion', Ethnic and Racial Studies, 36 (7), 1180-98.

de Vries, L. and E. Guild (2019), 'Seeking Refuge in Europe: Spaces of Transit and the Violence of Migration Management', Journal of Ethnic and Migration Studies, 45 (12), 2156-66.

Dijstelbloem, H. and A. Meijer (2011), Migration and the New Technological Borders of Europe, Basingstoke: Palgrave Macmillan.

Duez, D. and R. Bellanova (2012), 'A Different View on the "Making" of European Security: The EU Passenger Name Record System as a Socio-technical Assemblage', European Foreign Affairs Review, 17 (special issue), 109-24.

Ellermann, A. (2020), 'Discrimination in Migration and Citizenship' (Introduction to special issue), Journal of Ethnic and Migration Studies, 46 (12), 2463-79.

El Qadim, N., B. Beste İşleyen, L. A. de Vries, S. S. Hansen, S. Karadağ, D. Lisle and D. Simonneau (2020), '(Im)moral Borders in Practice', Geopolitics, DOI: 10.1080/14650045.2020.1747902.

Eule, T. G., L. M. Borrelli, A. Lindberg and A. Wyss (2018), Migrants Before the Law: Contested Migration Control in Europe, New York: Palgrave Macmillan.

Faist, T. and E. Özveren (2004), Transnational Social Spaces: Agents, Networks and Institutions, Aldershot: Ashgate.

Fanon, F. (2008 [1967]), Black Skin, White Masks, London, Pluto.

Feldman, G. (2011), 'Illuminating the Apparatus: Steps Toward a Nonlocal Ethnography of Global Governance', in C. Shore, S. Wright and D. Però (eds), Policy Worlds: Anthropology and the Analysis of Contemporary Power, New York et al., Berghahn Books, pp. 32-49.

Fiddian-Qasmiyeh, E., M. Berg and J. Waters (eds) (2020), Special Issue on 'Recentering the South in Studies of Migration', Migration and Society, issue 3.

Fiddian-Qasmiyeh, E. with J. Fiori (2020), 'Migration, Humanitarianism and the Politics of Knowledge', Migration and Society, 3 (1), 180-89.

Foucault, M. (2007), Security, Territory, Population: Lectures at the Collège de France, 1977-1978, Basingstoke: Palgrave Macmillan.

Freeman, G. P. (1995), 'Modes of Immigration Politics in Liberal Democratic-States', International Migration Review, 29 (4), 881-902.

Gaibazzi, P. (2017), 'From Expulsion to Extortion: Deportability, Predatory Policing and West African Migrants in Angola', Citizenship Studies, 21 (8), 969-83. 
Garcés-Mascareñas, B. (2019), 'Beyond Methodological Western-centrism. The "control gap” Debate Reconsidered from a Global Perspective', in A. Weinar, S. Bonjour and L. Zhyznomirska (eds), The Routledge Handbook of the Politics of European Migration, London: Routledge, pp. 50-59.

Geddes, A. and P. Scholten (2016), The Politics of Migration and Immigration in Europe, second edition, Basingstoke: Palgrave Macmillan.

Geiger, M. and A. Pécoud (2010), The Politics of International Migration Management, Basingstoke: Palgrave Macmillan.

Gill, N., R. Rotter, A. Burridge, M. Griffiths and J. Allsopp (2015), 'Inconsistency in Asylum Appeal Adjudication', Forced Migration Review, 50, 52-4.

Grieve, T. and R. Mitchell (2020), 'Promoting Meaningful and Equitable Relationships? Exploring the UK's Global Challenges Research Fund (GCRF) Funding Criteria from the Perspectives of African Partners', European Journal of Development Research, 32 (3), 514-28.

Haile, S. (2020), 'Voices to be Heard? Reflections on Refugees, Strategic Invisibility and the Politics of Voice', in E. Fiddian-Qasmiyeh (ed.), Refuge in a Moving World, London: UCL Press, ch. 2.

Hansen, P. and S. Jonsson (2014), Eurafrica, London: Bloomsbury.

Heinelt, H. (1993), 'Policy und Politics. Überlegungen zum Verhältnis von Politikinhalten und Politikprozessen', in A. Windhoff-Héritier (ed.), Policy-Analyse. Wiesbaden: VS Verlag für Sozialwissenschaften, pp. 307-27.

Hill Collins, P. (2002), Black Feminist Thought: Knowledge, Consciousness, and the Politics of Empowerment, London: Routledge.

Hoag, C. (2010), 'The Magic of the Populace: An Ethnography of Illegibility in the South African Immigration Bureaucracy', Political and Legal Anthropology Review, 33 (1), 6-25.

Hollifield, J. F. (1992), Immigrants, Markets, and States: The Political Economy of Postwar Europe, Cambridge, MA: Harvard University Press.

Hollifield, J. F. (2000), 'The Politics of International Migration: How Can we Bring the State Back in?', in C. Brettell and J. F. Hollifield (eds), Migration Theory: Talking Across Disciplines, London, New York: Routledge, pp. 137-85.

Huysmans, J. (2000), 'The European Union and the Securitization of Migration', Journal of Common Market Studies, 38 (5), 751-77.

Hyndman, J. and W. Giles (2011), 'Waiting for What? The Feminization of Asylum in Protracted Situations', Gender, Place \& Culture, 18 (3), 361-79.

Isin, E. F. (2002), Being Political: Genealogies of Citizenship, Minneapolis: University of Minnesota Press.

Jacobsen, K. (2006), 'Refugees and Asylum Seekers in Urban Areas: A Livelihoods Perspective', Journal of Refugee Studies, 19(3), 273-86.

Jacobsen, K. L. (2017), 'On Humanitarian Refugee Biometrics and New Forms of Intervention', Journal of Intervention and Statebuilding, 11 (4), 529-51.

Jaji, R. (2011), 'Social Technology and Refugee Encampment in Kenya', Journal of Refugee Studies, 25 (2), 221-38.

Jaji, R. (2013), 'Somali Asylum Seekers and Refoulement at the Kenya-Somalia Border', Journal of Borderlands Studies, 28 (3), 355-68.

Jessop, B. (2016), The State: Past, Present, Future. Cambridge and Malden, MA: Polity Press.

Johnson, H. L. (2011), 'Click to Donate: Visual Images, Constructing Victims and Imagining the Female Refugee', Third World Quarterly, 32 (6), 1015-37.

Joppke, C. (1998), 'Immigration Challenges the Nation-state', in C. Joppke (ed.), Challenge to the Nation-State: Immigration in Western Europe and the United States, Oxford: Oxford University Press, pp. 5-46.

Joppke, C. (2005), 'Exclusion in the Liberal State: The Case of Immigration and Citizenship Policy', European Journal of Social Theory, 8 (1), 43-61.

Kofman, E. (2013), 'Gendered Labour Migrations in Europe and Emblematic Migratory Figures', Journal of Ethnic and Migration Studies, 39 (4), 579-600.

Kofman, E. and P. Raghuram (2015), Gendered Migrations and Global Social Reproduction, Basingstoke: Palgrave Macmillan.

Landau, L. B. and Achiume, E. T. (2017), 'Misreading Mobility? Bureaucratic Politics and Blindness in UN Migration Reports', Development and Change, 48 (5), 1182-95. 
Lee, A. E. (2013), “'Illegality”, health problems, and return migration', Regions \& Cohesion, 3 (1), 62-93.

Leese, M. (2014), 'The New Profiling: Algorithms, Black Boxes, and the Failure of Anti-Discriminatory Safeguards in the European Union', Security Dialogue, 45, 494-511, https://doi.org/10.1177/ 0967010614544204.

Leese, M. (2016), 'Exploring the Security/Facilitation Nexus: Foucault at the "Smart” Border', Global Society, 30, 412-29, https://doi.org/10.1080/13600826.2016.1173016.

Lenner, K. (2020), "'Biting Our Tongues": Policy Legacies and Policy Memories in the Making of the Syrian Refugee Response in Jordan', Refugee Survey Quarterly, 39 (3), 273-298.

Lenner, K. and L. Turner (2019), 'Making Refugees Work? The Politics of Integrating Syrian Refugees into the Labour Market in Jordan', Middle East Critique, 28 (1), 65-95.

Long, K. (2013), 'When Refugees Stopped Being Migrants: Movement, Labour and Humanitarian Protection', Migration Studies, 1 (1), 4-26.

Mayblin, L. (2014), 'Colonialism, Decolonisation, and the Right to be Human: Britain and the 1951 Geneva Convention on the Status of Refugees', Journal of Historical Sociology, 27 (3), 423-41.

Mayblin, L and J. Turner (2020), Migration Studies and Colonialism, Cambridge: Polity Press.

Medland, L. (2017), 'Misconceiving "Seasons" in Global Food Systems: The Case of the EU Seasonal Workers Directive', European Law Journal, 23 (3-4), 157-71.

Meeus, B. (2016), 'Migration and Postsocialism: A Relational Geography Approach', in A. Amelina, B. Meeus and K. Horvath (eds), An Anthology of Migration and Social Transformation. European Perspectives, Heidelberg: Springer, pp. 87-100.

Menjívar, C. (2006), 'Liminal Legality: Salvadoran and Guatemalan Immigrants' Lives in the United States', American Journal of Sociology, 111 (4), 999-1037.

Menz, G. (2009), The Political Economy of Managed Migration, Oxford: Oxford University Press.

Mignolo, W. (2012), Local Histories/Global Designs: Coloniality, Subaltern Knowledges, and Border Thinking, Princeton, NJ: Princeton University Press.

Mignolo, W. and C. Walsh (2018), On Decoloniality: Concepts, Analytics, Praxis, Durham, NC: Duke University Press.

Moran, D., N. Gill and D. Conlon (2013), Carceral Spaces: Mobility and Agency in Imprisonment and Migrant Detention, Aldershot: Ashgate.

Mosse, D. (2004), 'Is Good Policy Unimplementable? Reflections on the Ethnography of Aid Policy and Practice', Development and Change, 35 (4), 639-71.

Nassar, J. and N. Stel (2019), 'Lebanon's Response to the Syrian Refugee Crisis - Institutional Ambiguity as a Governance Strategy', Political Geography, 70, 44-54.

Natter, K. (2018), 'Rethinking Immigration Policy Theory Beyond "Western Liberal Democracies", Comparative Migration Studies, 6 (1), 1-21.

Neocosmos, M. (2008), 'The Politics of Fear and the Fear of Politics: Reflections on Xenophobic Violence in South Africa', Journal of Asian and African Studies, 43 (6), 586-94.

Nyers, P. (2018), Irregular Citizenship, Immigration, and Deportation, London: Routledge.

Oesch, L. (2017), 'The Refugee Camp as a Space of Multiple Ambiguities and Subjectivities', Political Geography, 60, 110-20.

O’Higgins, A. (2012), 'Vulnerability and Agency: Beyond an Irreconcilable Dichotomy for Social Service Providers Working with Young Refugees in the UK', New Directions for Child and Adolescent Development, 136, 79-91, DOI: 10.1002/cad.20012.

Paul, R. (2015), The Political Economy of Border-Drawing: Arranging Legality in European Labor Migration Policies, Oxford and New York: Berghahn.

Paul, R. (2016), 'Negotiating Varieties of Capitalism? Crisis and Change in Contemporary British and German Labour Migration Policies', Journal of Ethnic and Migration Studies, 42 (10), 1631-50.

Paul, R. (2019), 'Risk Analysis as a Governance Tool in European Border Control', in A. Weinar, S. Bonjour and L. Zhyznomirska (eds), The Routledge Handbook of the Politics of European Migration, London: Routledge, pp. 227-38.

Perkowski, N. and V. Squire (2019), 'The Anti-Policy of European Anti-Smuggling as a Site of Contestation in the Mediterranean Migration "Crisis", Journal of Ethnic and Migration Studies, 45 (12), 2167-84. 
Però, D. (2011), 'Migrants' Practices of Citizenship and Policy Change', in C. Shore, S. Wright and D. Però (eds), Policy Worlds: Anthropology and the Analysis of Contemporary Power, New York et al.: Berghahn Books, pp. 244-63.

Piore, M. J. (1979), Birds of Passage: Migrant Labor and Industrial Societies, Cambridge: Cambridge University Press.

Plambech, S. (2014), 'Between "Victims" and "Criminals": Rescue, Deportation, and Everyday Violence Among Nigerian Migrants', Social Politics, 21 (3), 382-402.

Pott, A., C. Rass and F. Wolff (eds) (2018), Was ist ein Migrationsregime? [What Is a Migration Regime?], Berlin: VS Verlag für Sozialwissenschaften.

Raghuram, P. (2009), 'Which Migration, What Development? Unsettling the Edifice of Migration and Development', Population, Space and Place, 15, 103-17.

Rijken, C. and T. de Lange (eds) (2018), Towards a Decent Labour Market for Low Waged Migrant Workers, Amsterdam: Amsterdam University Press.

Rose, N. (1999), Powers of Freedom: Reframing Political Thought, Cambridge: Cambridge University Press.

Ruhs, M. (2013), The Price of Rights: Regulating International Labor Migration, Princeton, NJ: Princeton University Press.

Rygiel, K. and P. Nyers (eds) (2012), Citizenship, Migrant Activism and the Politics of Movement, London: Routledge.

Santos, B.d.S. (2015), Epistemologies of the South: Justice against Epistemicide, London: Routledge, https:/globalsocialtheory.org/thinkers/santos-boaventura-de-sousa/.

Sassen, S. (1999), Guests and Aliens, New York: New Press.

Sassen, S. (2014), ‘Anti-Immigrant Politics Along with Institutional Incorporation?', in M. Walton-Roberts and J. Hennebry (eds), Territoriality and Migration in the E.U., Dordrecht: Springer, pp. 13-26.

Saunders, N. (2014), 'Paradigm Shift or Business as Usual? An Historical Appraisal of the "Shift" to the Securitization of Refugee Protection', Refugee Survey Quarterly, 33 (3), 69-92.

Scheibelhofer, E., N. Regös and C. Holzinger (2019), 'Navigating the Labyrinths of Transnational Social Security: Experiences and Meaning-Making Processes of EU Migrants When Accessing and Porting Social Rights', in A. Amelina, E. Carmel, A. Runfors and E. Scheibelhofer (eds), Boundaries of European Social Citizenship, London: Routledge, chapter 5.

Schwenken, H. and S. Ruß-Sattar (2014), New Border and Citizenship Politics, London: Palgrave Macmillan.

Scott, J., (1998), Seeing Like a State: How Certain Schemes to Improve the Human Condition Have Failed, New Haven, CT: Yale University Press.

Sharma, N. (2015), 'Strategic Anti-essentialism: Decolonising Decolonization', in K. McKittrick (ed.), Syliva Wynter: On being Human as Praxis, Durham, NC: Duke University Press, pp. 164-82.

Sigona, N. (2014), 'Campzenship: Reimagining the Camp as a Social and Political Space', Citizenship Studies, 19 (1), 1-15.

Stel, N. (forthcoming), 'Uncertainty, Exhaustion, Abandonment - Leveraging the Idea of Strategic Institutional Ambiguity to Interrogate North/South Distinctions in Forced Migration Studies', Political Geography.

Stierl, M. (2015), 'The WatchTheMed Alarm Phone: A Disobedient Border-Intervention', Movements: Journal for Critical Migration and Border Regime Studies 1 (2), http://movements-journal.org/issues/ 02.kaempfe/13.stierl--watchthemed-alarmphone.html.

Stone, D. (2012), Policy Paradox: The Art of Political Decision Making, New York: W.W. Norton \& Co.

Sukarieh, M. and S. Tannock (2019), 'Subcontracting Academia: Alienation, Exploitation and Disillusionment in the UK Overseas Syrian Refugee Research Industry', Antipode, 51 (2), 664-80.

Sum, N. L. and B. Jessop (2013), Towards a Cultural Political Economy, Cheltenham, UK and Northampton, MA, USA: Edward Elgar Publishing.

Taylor, L. and Meissner, F. (2020), 'A Crisis of Opportunity: Market-Making, Big Data, and the Consolidation of Migration as Risk', Antipode, 52, 270-90. https://doi.org/10.1111/anti.12583.

Tazzioli, M. (2018), 'Spy, Track and Archive: The Temporality of Visibility in Eurosur and Jora', Security Dialogue, 49 (4), 272-88.

Tazzioli, M. (2019), 'Refugees' Debit Cards, Subjectivities, and Data Circuits: Financial-Humanitarianism in the Greek Migration Laboratory', International Political Sociology, 13 (4), 392-408. 
Tilly, C. (2011), 'The Impact of the Economic Crisis on International Migration: A Review', Work, Employment and Society, 25 (4), 675-92.

Torpey, J. (2000), The Invention of the Passport: Surveillance, Citizenship and the State, Cambridge: Cambridge University Press.

Triandafyllidou, A. (2019), The Migration Archipelago: Social Navigation and Migrant Agency', International Migration, 57, 5-19.

Tuhiwai-Smith, L. (1999), Decolonizing Methodologies: Research and Indigenous Peoples, London: Zed Books.

Turner, L. (2019), 'Syrian Refugee Men as Objects of Humanitarian Care', International Feminist Journal of Politics, 21 (4), 595-616.

Vintila, D. and Lafleur, J.M. (2020), 'Migration and access to welfare benefits in the EU: The interplay between residence and nationality', in J.M. Lafleur and D. Vintila (eds), Migration and Social Protection in Europe and Beyond (Volume 1), Charm: Springer, pp. 1-32.

Walters, W. (2008), 'Putting the Migration-Security Complex in its Place', in L. Amoore and M. de Goede (eds), Risk and the War on Terror, Oxford: Routledge, pp. 158-77.

Walters, W. (2015), 'Migration, Vehicles, and Politics: Three Theses on Visapolitics', European Journal of Social Theory, 18 (4), 469-88.

Walters, W. (2017), 'Live Governance, Borders, and the Time-Space of the Situation: EUROSUR and the Genealogy of Bordering in Europe', Comparative European Politics, 15 (5), 794-817.

Wedel, J. R., C. Shore, G. Feldman and S. Lathrop (2005), 'Toward an Anthropology of Public Policy', The ANNALS of the American Academy of Political and Social Science, 600 (1), 30-51.

Weinar, A. (2019), 'Politics of Emigration in Europe', in A. Weinar, S. Bonjour and L. Zhyznomirska (eds), The Routledge Handbook of the Politics of European Migration, London: Routledge, pp. 38-49.

Wimmer, A. and N. Glick Schiller (2002), 'Methodological Nationalism and Beyond: Nation-State Building, Migration and the Social Sciences', Global Networks, 2 (4), 301-34.

Wynter, S. (2003), 'Unsettling the Coloniality of Being/Power/Truth/Freedom: Towards the Human, after Man, Its Overrepresentation - An Argument', The New Centennial Review, 3 (3), 257-337. 